\title{
Influence of age and Helicobacter pylori infection on serum pepsinogens in healthy blood transfusion donors
}

\author{
R A Veenendaal, I Biemond, A S Peña, W van Duijn, J Kreuning, C B H W Lamers
}

\begin{abstract}
In a healthy population pepsinogen $A$ and pepsinogen $C$ increase with advancing age. As pepsinogen $A$ and $C$ are raised in chronic superficial gastritis which is caused by $\boldsymbol{H}$ pylori infection, we investigated whether $\boldsymbol{H}$ pylori is responsible for the age related increase of pepsinogen $A$ and $C$. In $H$ pylori positive blood transfusion donors serum pepsinogen $\mathbf{A}$ (mean (SD) $73(35) \mu \mathrm{g} / \mathrm{ml} v 52(19) \mu \mathrm{g} / \mathrm{ml}, \mathrm{p}<<0.01)$ and $C$ (mean (SD) $24(13) \mu \mathrm{g} / \mathrm{ml} v 10(7) \mu \mathrm{g} / \mathrm{ml}$, $\mathrm{p}<<0.01)$ concentrations were significantly higher than in $H$ pylori negative blood transfusion donors, while the serum pepsinogen $A: C$ ratio (mean (SD) 3.5 (1.4) v 6.2 (3.4), $\mathrm{p}<<0.01)$ was significantly decreased because of a relative greater increase in serum pepsinogen $\mathrm{C}$ in $\boldsymbol{H}$ pylori positive blood transfusion donors. Analysis of variance showed that pepsinogen $A$ and $C$ concentrations differed significantly in the different age groups $(p<<0.01)$ when we considered all blood transfusion donors and $H$ pylori positive blood transfusion donors, the mean pepsinogen levels being highest in the older age categories. In $\boldsymbol{H}$ pylori negative blood transfusion donors no such age related difference in pepsinogen $A$ and $C$ could be shown. In $H$ pylori positive blood transfusion donors a weak positive but significant correlation between pepsinogen $A$ and $C$ and age could be shown $(r=0.30 ; p=0.01$ and $\mathrm{r}=0.31 ; \mathrm{p}=0.01$ respectively). In $\boldsymbol{H}$ pylori negative blood transfusion donors no correlation between serum pepsinogens and age was found. We conclude that the age related increase in serum pepsinogen $A$ and $C$ described in healthy control populations is caused by an increasing prevalence of $\boldsymbol{H}$ pylori infection. Serum pepsinogen $A$ and $C$ concentrations in patients should therefore be related to the presence or absence of $\boldsymbol{H}$ pylori infection.
\end{abstract}

Gastroenterology Leiden University Hospital, Leiden, The Netherlands

R A Veenendaal

I Biemond

A S Peña

W van Duijn

J Kreuning

C B H W Lamers

Correspondence to

R A Veenendaal, $M D$, Department of Gastroenterology, Leiden University Hospital, Building 1, C4-P14, PO Box 9600, 2300 RC Leiden, The Netherlands.

Accepted for publication 29 July 1991

Pepsinogen $A$ and $C$ are the proenzymes of pepsin A and pepsin C, respectively, which belong to the group of gastric acid aspartic endoproteinases. Pepsinogen $A$ is secreted by the fundic mucosa' while pepsinogen $C$ is secreted by fundic glands, pyloric glands, and proximal duodenal mucosa.

Serum pepsinogen A and pepsinogen $\mathrm{C}$ concentrations can predict the histological status of the gastric mucosa and show also non-parallel changes in serum concentrations with increasing severity of gastritis ${ }^{3+}$ showing a relatively greater rise of pepsinogen $\mathrm{C}$ in patients with more severe gastritis. In healthy controls an increase in pepsinogen $\mathrm{A}$ and pepsinogen $\mathrm{C}$ serum concentrations with age has been described by several authors. ${ }^{5-7}$ The incidence of $H$ pylori infection increases with age ${ }^{89}$ and $H$ pylori is generally accepted as the cause of chronic superficial gastritis ${ }^{1011}$ which can be a cause of increased serum pepsinogen $A$ and $C$ levels. ${ }^{312} 13$ We therefore investigated the influence of $H$ pylori infection on the age related increase of pepsinogen $\mathrm{A}$ and pepsinogen $\mathrm{C}$ concentrations in healthy blood transfusion donors.

\section{Methods}

SUBJECTS

We examined sera obtained from 122 male and 69 female blood transfusion donors. The maximum age of these blood transfusion donors was 59 years. The age distribution of these donors is shown in Table I. IgG and IgA serum antibodies against $H$ pylori and the serum concentrations of pepsinogen $\mathrm{A}$ and $\mathrm{C}$ were determined.

\section{ANTI-H PYLORI ANTIBODIES}

Specific IgA and IgG antibodies against $H$ pylori were measured by a modified ELISA technique for IgA and IgG using conjugates labelled with immunoperoxidase specific for human $\operatorname{IgA}$ and IgG. The results were expressed as the absorbance index $(\mathrm{AI})$ :

$A I=$ mean OD reading $(n=2)$ of patient's serum - mean OD of blank reading mean OD reading $(n=2)$ of reference serum - mean OD of blank reading where OD is the optical density. The procedure of the assay and determination of intra- and interassay variability of the ELISA technique has been decribed in detail by Peña et al.1+
TABLE I Analysis of variance of the serum pepsinogen $A$ concentrations in blood transfusion donors with and without serological evidence of $\mathrm{H}$ pylori infection stratified according to age

\begin{tabular}{llll}
\hline $\begin{array}{l}\text { Age categories } \\
\text { (yr) }\end{array}$ & All donors & $\begin{array}{l}\text { H pulori } \\
\text { (Negative) }\end{array}$ & $\begin{array}{l}\text { H pylori } \\
\text { (Positive) }\end{array}$ \\
\hline $20-29$ & $49(18)[58]$ & $47(6)[40]$ & $52(23)[18]$ \\
$30-39$ & $61(29)[60]$ & $53(21)[47]$ & $89(38)[13]$ \\
$40-49$ & $63(27)[52]$ & $54(20)[27]$ & $73(30)[25]$ \\
$50-59$ & $73(34)[21]$ & $55(13)[11]$ & $93(41)[10]$ \\
All ages & $59(27)[191]$ & $52(19)[125]$ & $73(35)[66]^{\star}$ \\
F test on age & 5.49 & $1 \cdot 21$ & $4 \cdot 94$ \\
p value & $<0.01$ & NS & $<0.01$ \\
\hline
\end{tabular}

* F test on presence of $H$ pylori $=30 \cdot 70$ ( $\mathrm{p}$ value $=<<0 \cdot 01$ ); Mean (SD) [no] of serum pepsinogen A concentrations ( $\mu \mathrm{g} / \mathrm{l})$ 
Serum with an $\mathrm{AI}>0.32$ for IgG anti- $H$ pylori was considered evidence of $H$ pylori infection.

PEPSINOGEN A AND PEPSINOGEN C

Serum pepsinogen $A$ and $C$ concentrations were determined by specific and sensitive radio-

TABLE II Analysis of variance of the serum pepsinogen $C$ concentrations in blood transfusion donors with and without serological evidence of $\mathrm{H}$ pylori infection stratified according to age

\begin{tabular}{llcl}
\hline $\begin{array}{l}\text { Age categories } \\
\text { (yr) }\end{array}$ & All donors & $\begin{array}{l}\text { H pylori } \\
\text { (Negative) }\end{array}$ & $\begin{array}{l}\text { H pylori } \\
\text { (Positive) }\end{array}$ \\
\hline $20-29$ & $11(7)[58]$ & $9(5)[40]$ & $15(8)[18]$ \\
$30-39$ & $15(13)[60]$ & $11(9)[47]$ & $29(16)[13]$ \\
$40-49$ & $17(11)[52]$ & $10(5)[27]$ & $25(11)[25]$ \\
$50-59$ & $19(16)[21]$ & $8(3)[11]$ & $31(16)[10]$ \\
All ages & $15(11)[191]$ & $10(7)[125]$ & $24(13)[66]^{\star}$ \\
F test on age & 3.66 & 1.01 & 4.82 \\
p value & 0.01 & NS & $<0.01$ \\
\hline
\end{tabular}

$\star F$ test on presence of $H$ pylori $=92.82$ ( $\mathrm{p}$ value $=<<0.01$ ); Mean (SD) [no] of serum pepsinogen C concentrations $(\mu \mathrm{g} / \mathrm{l})$

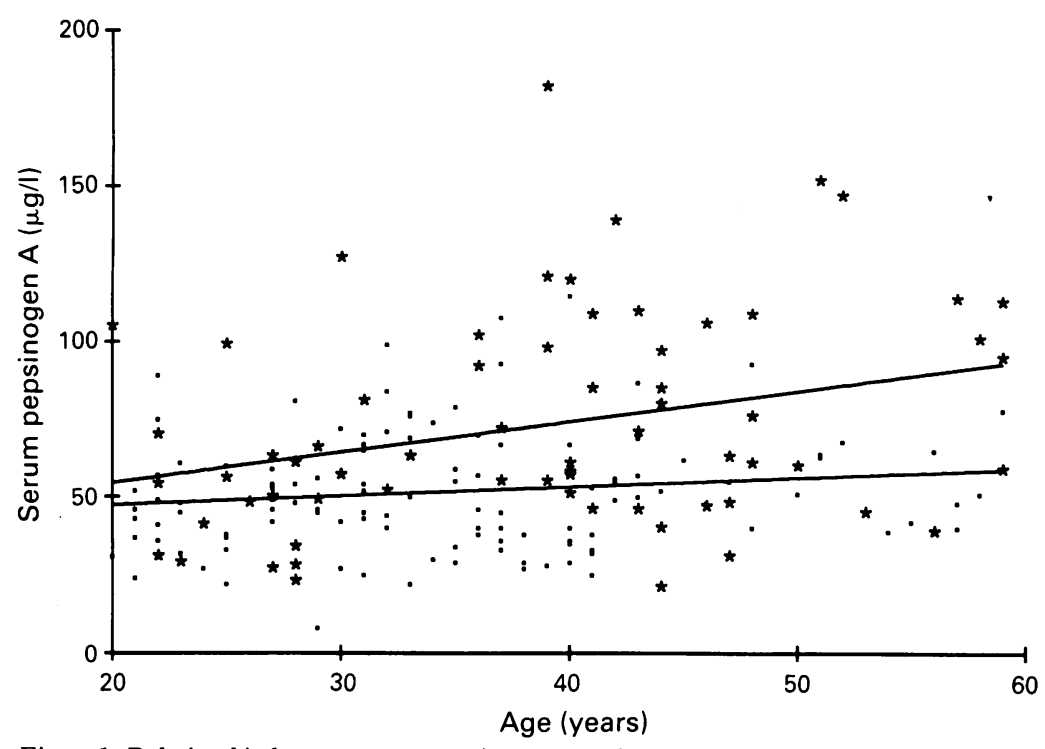

Figure 1: Relationship between serum pepsinogen $A$ and age in $\mathrm{H}$ pylori positive $\left(^{\star}\right)$ and $\mathrm{H}$ pylori negative (O) blood transfusion donors. Upper line: regression line $(r=0 \cdot 30 ; p=0 \cdot 01)$ in $\mathrm{H}$ pylori positive blood transfusion donors. Lower line: regression line $(r=0 \cdot 15 ; p=0 \cdot 10)$ in $\mathbf{H}$ pylori negative blood transfusion donors.

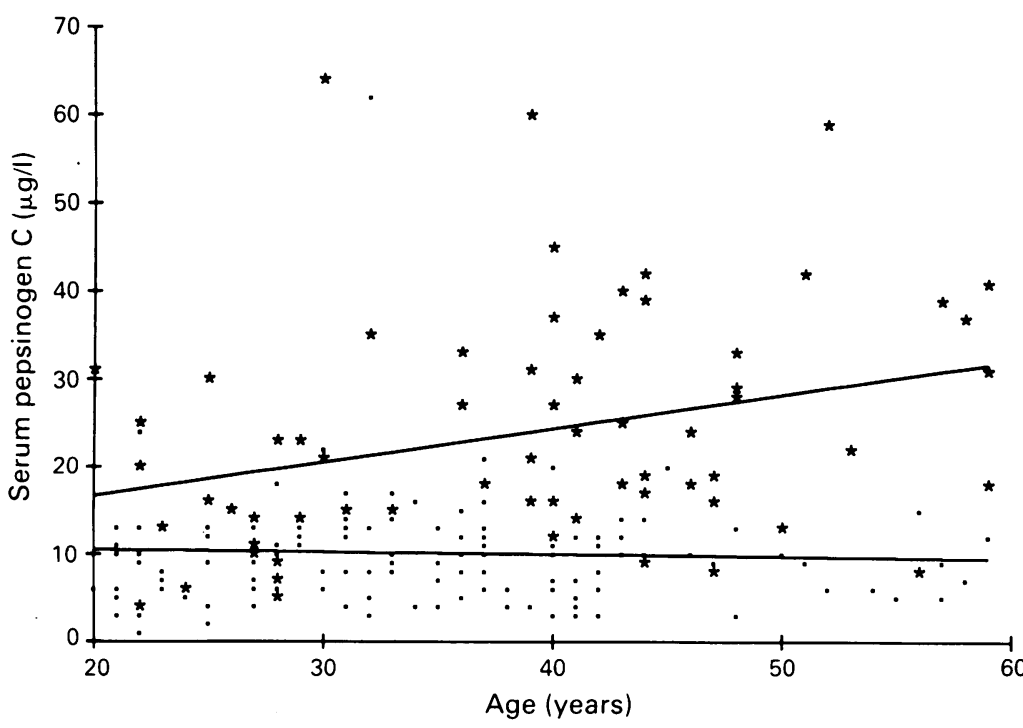

Figure 2: Relationship between serum pepsinogen $C$ and age in $\mathrm{H}$ pylori positive ${ }^{\star}\left({ }^{\prime}\right)$ and $\mathrm{H}$ pylori negative (O) blood transfusion donors. Upper line: regression line $(r=0 \cdot 31 ; p=0.01)$ in $\mathrm{H}$ pylori positive blood transfusion donors. Lower line: regression line $(r=-0.04 ; p=0.69)$ in $\mathrm{H}$ pylori negative blood transfusion donors. immunoassays. Both techniques were developed in our department and have been validated in previous studies. ${ }^{6}$

The intraassay coefficients of variation varied from $3 \cdot 0 \%$ to $10 \cdot 2 \%$ at serum concentrations in the normal range for pepsinogen $\mathrm{A}$ and from $12 \cdot 6$ to $14 \cdot 7 \%$ serum levels in the normal range for

TABLE III Analysis of variance of the serum pepsinogen $A: C$ ratios in blood transfusion donors with and without serological evidence of $\mathrm{H}$ pylori infection stratified according to age

\begin{tabular}{llll}
\hline $\begin{array}{l}\text { Age categories } \\
\text { (yr) }\end{array}$ & All donors & $\begin{array}{l}\text { H pylori } \\
(\text { Negative })\end{array}$ & $\begin{array}{l}\text { H pylori } \\
(\text { Positive })\end{array}$ \\
\hline $20-29$ & $5 \cdot 6(4 \cdot 1)[58]$ & $6 \cdot 4(4 \cdot 6)[40]$ & $4 \cdot 1(1 \cdot 9)[18]$ \\
$30-39$ & $5 \cdot 1(2 \cdot 2)[60]$ & $5 \cdot 5(2 \cdot 2)[47]$ & $3 \cdot 4(1 \cdot 1)[13]$ \\
$40-49$ & $5 \cdot 0(3 \cdot 1)[52]$ & $6 \cdot 7(3 \cdot 4)[27]$ & $3 \cdot 1(1 \cdot 2)[25]$ \\
$50-59$ & $5 \cdot 2(2 \cdot 4)[21]$ & $7 \cdot 0(1 \cdot 9)[11]$ & $3 \cdot 2(0 \cdot 9)[10]$ \\
All ages & $5 \cdot 2(3 \cdot 1)[191]$ & $6 \cdot 2(3 \cdot 4)[125]$ & $3 \cdot 5(1 \cdot 4)[66]^{\star}$ \\
F test on age & $0 \cdot 58$ & $1 \cdot 11$ & $1 \cdot 65$ \\
p value & NS & NS & NS \\
\hline
\end{tabular}

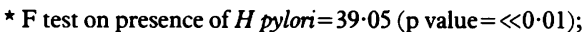
Mean (SD) [no] of serum pepsinogen A:C ratios

pepsinogen C. All samples were measured in duplicate in the same assay. At all time intervals serum pepsinogen $\mathrm{A}: \mathrm{C}$ ratios were calculated.

STATISTICAL ANALYSIS

Analysis of variance was used to compare the test results in the different age categories and with respect to $H$ pylori infection. The association between age and different test results was investigated by linear regression analysis and graphically displayed.

\section{Results}

In this study 191 healthy blood transfusion donors were studied, 70 donors had serological evidence of $H$ pylori infection.

Mean serum pepsinogen A and C concentrations in $H$ pylori positive blood transfusion donors were significantly $(\mathrm{p}<<0 \cdot 01)$ higher than in $H$ pylori negative donors (Tables I, II). Analysis of variance showed that pepsinogen A and $C$ concentrations differed significantly in the different age categories when we considered all blood transfusion donors (pepsinogen $\mathrm{A}: \mathrm{F}=$ $5.49, \mathrm{p}<0.01$, pepsinogen $\mathrm{C}: \mathrm{F}=3.66, \mathrm{p}=0.01$ ) and $H$ pylori positive blood transfusion donors (pepsinogen A: $F=4.94, p<0.01$, pepsinogen $C$ : $F=4.82, p<0.01$ ), the mean pepsinogen $A$ and $C$ concentrations being the highest in the older age categories. In $H$ pylori negative blood transfusion donors no difference of pepsinogen $A$ and $C$ concentrations could be shown in the different age categories (pepsinogen $A: F=1 \cdot 2 l, p=n s$, pepsinogen $C: F=1 \cdot 01, p=n s)$. Serum pepsinogen $C$ showed a relatively greater increase in than pepsinogen A in $H$ pylori positive transfusion donors. The above described non-parallel changes in serum pepsinogen $\mathrm{A}$ and $\mathrm{C}$ concentrations resulted in a significant $(\mathrm{p}<<0.01)$ lower mean serum pepsinogen $\mathrm{A}: \mathrm{C}$ ration in $H$ pylori positive blood transfusion donors (Table III). Analysis of variance failed to show significant changes of pepsinogen $\mathrm{A}: \mathrm{C}$ ratio in the different age categories in all blood transfusion donors regardless of their $H$ pylori status (Table III). 


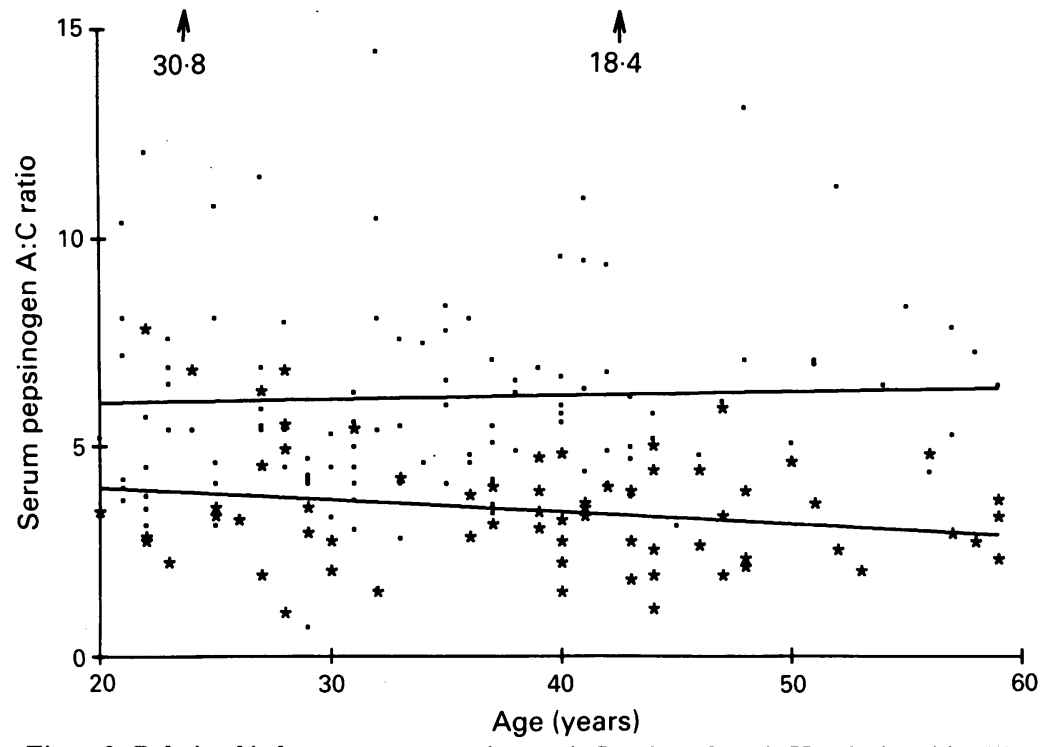

Figure 3: Relationship between serum pepsinogen $A: C$ ratio and age in $\mathrm{H}$ pylori positive $\left.{ }^{\star}{ }^{\star}\right)$ and $\mathrm{H}$ pylori negative $(O)$ blood transfusion donors. Upper line: regression line $(r=0.03$; $p=0 \cdot 76)$ in $\mathrm{H}$ pylori negative blood transfusion donors. Lower line: regression line $(r=-0 \cdot 21$; $p=0.9)$ in $\mathrm{H}$ pylori positive blood transfusion donors.

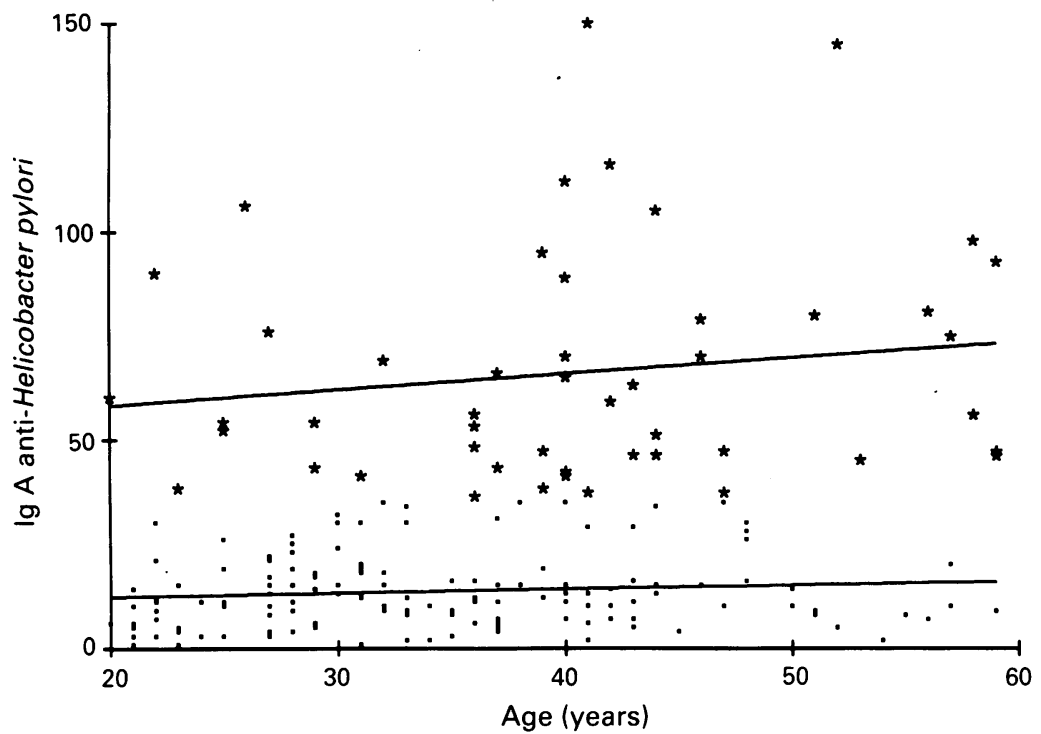

Figure 4: Relationship between the IgA absorbance index and age in $\mathrm{H}$ pylori positive $\left(^{\star}\right)$ and $\mathrm{H}$ pylori negative (O) blood transfusion donors. Upper line: regression line $(r=0 \cdot 27 ; p=0 \cdot 03)$ in $\mathrm{H}$ pylori negative blood transfusion donors. Lower line: regression line $(r=0 \cdot 16 ; p=0 \cdot 07)$ in $\mathbf{H}$ pylori positive blood transfusion donors.

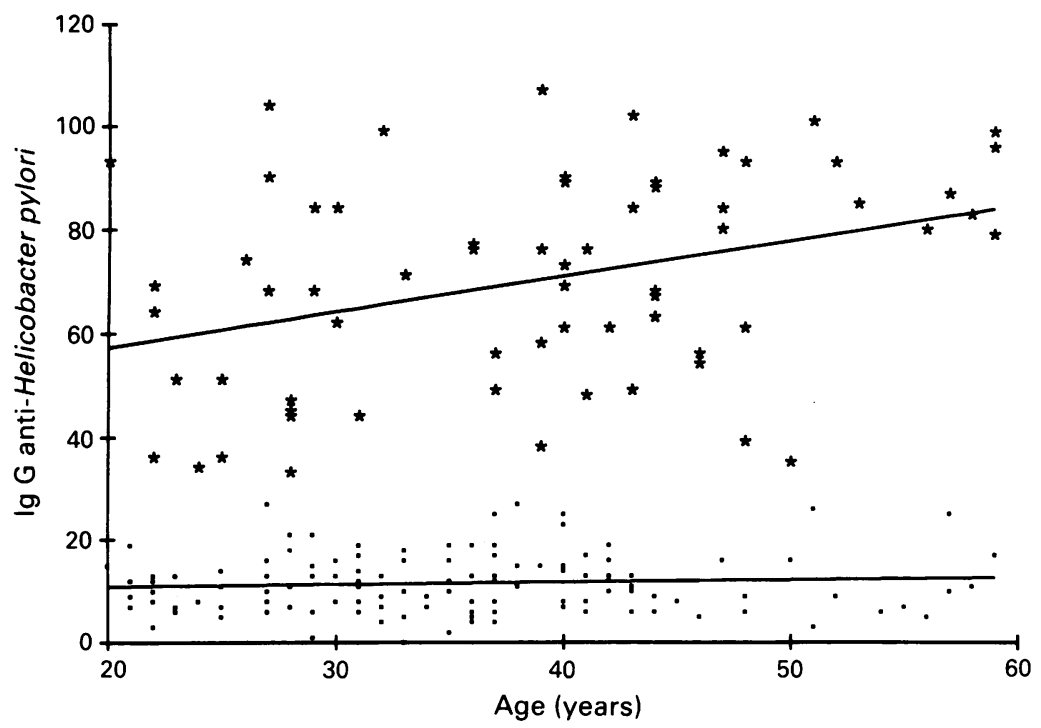

Figure 5: Relationship between the IgG absorbance index and age in $\mathrm{H}$ pylori positive $\left(^{\star}\right)$ and $\mathbf{H}$ pylori negative (O) blood transfusion donors. Upper line: regression line $(r=0.36 ; p=0.03)$ in $\mathrm{H}$ pylori negative blood transfusion donors. Lower line: regression line $(r=0.07 ; p=0.42)$ in $\mathrm{H}$ pylori positive blood transfusion donors.
Serum pepsinogen $\mathrm{A}$ and $\mathrm{C}$ concentrations in $H$ pylori positive and $H$ pylori negative donors were plotted against age (Figs 1,2) showing no correlation between age and serum pepsinogen $A(r=0 \cdot 15 ; p=0 \cdot 10)$ or serum pepsinogen $\mathrm{C}(\mathrm{r}=-0.04 ; \mathrm{p}=0.69)$ in $H$ pylori negative donors. In $H$ pylori positive blood transfusion donors a weak but significant correlation between age and both serum pepsinogen $A$ $(\mathrm{r}=0 \cdot 30, \mathrm{p}=0 \cdot 01$, Figure 1$)$ and serum pepsinogen $C(r=0.31, p=0.01$, Figure 2$)$ was found. No correlation between age and pepsinogen $A: C$ ratio $(r=-0.21, p=0.09$, Figure 3 ) could be found in $H$ pylori positive blood transfusion donors, nor in $H$ pylori negative blood transfusion donors.

The IgA and IgG absorbance index in $H$ pylori positive and $H$ pylori negative donors were also plotted against age showing no correlation between age and the $\operatorname{IgA}(r=0.16, p=0.07$, Figure 4) or the $\operatorname{IgG}(r=0.07, p=0.42$, Figure 5) absorbance index in $H$ pylori negative donors. In $H$ pylori positive blood transfusion donors a weak but significant correlation between age and both the $\operatorname{IgA}(r=0.27, p=0.03$, Figure 4$)$ and the $\operatorname{IgG}$ $(r=0.35, p=0.03$, Figure 5$)$ absorbance index was found.

\section{Discussion}

Serum pepsinogen $A$ and $C$ concentrations in an apparently healthy population increase with advancing age..$^{5-7}$ The non-parallel changes in serum pepsinogen $\mathrm{A}$ and $\mathrm{C}$ also cause a slight decrease in the serum pepsinogen $\mathrm{A}: \mathrm{C}$ ratio. ${ }^{67}$ As possible explanations for these phenomena both increasing pyloric gland metaplasia in the stomach $^{5}$ and loss of renal function with advancing age ${ }^{15-17}$ have been put forward.

Our findings indicate that in a healthy population consisting of blood transfusion donors significant differences in serum pepsinogen A and $\mathrm{C}$ exist between $H$ pylori positive and $H$ pylori negative subjects (Tables I, II). Infection with $H$ pylori is the cause of chronic superficial gastritis in which rises in pepsinogen $\mathrm{A}$ and $\mathrm{C}$ and a decrease in pepsinogen $\mathrm{A}: \mathrm{C}$ ratio have been described. ${ }^{31213}$ Treatment of $H$ pylori infection leads to an improvement of gastritis ${ }^{18}$ and also causes a decrease in pepsinogen $\mathrm{A}^{13}$ and $\mathrm{C}^{1920}$ with an increase in the pepsinogen $\mathrm{A}: \mathrm{C}$ ratio. As the incidence of $H$ pylori and its associated chronic superficial gastritis ${ }^{21} 22$ is higher in older age groups we suggest that the age dependent increase in serum pepsinogen $A$ and $C$ in a healthy control population is mainly caused by $H$ pylori infection leading to chronic superficial gastritis. This point of view is supported by the fact that in $H$ pylori negative blood transfusion donors no age related increase in serum pepsinogen concentrations could be found (Figs 1, 2 ). The slight but significant age related increase in serum pepsinogen $\mathrm{A}$ and $\mathrm{C}$ which we found in $H$ pylori positive blood transfusion donors can possibly be explained by assuming that after triggering of chronic superficial gastritis by $H$ pylori further progression of the gastritis occurs. ${ }^{23}$ In younger age groups chronic gastritis with minimal inflammatory infiltrate occurs in $H$ pylori positive patients. ${ }^{23}$ Longterm 
biopsy follow up studies of Finnish and Estonian outpatient and population samples have shown an age related increase of severity in chronic gastritis caused by $H$ pylori. ${ }^{25}$ Release of pepsinogen $\mathrm{A}$ and $\mathrm{C}$ into the circulation in response to this inflammation ${ }^{26}$ is probably the cause of the observed age related increase of pepsinogen A and $\mathrm{C}$ in $H$ pylori positive blood transfusion donors.

The cause of our finding that the IgA and IgG absorbance index show an increase with advancing age is unclear but might also reflect progression of chronic superficial gastritis with advancing age. Our findings suggest that the rise in serum pepsinogen $A$ which has been described in relatives of duodenal ulcer patients could be at least partly explained by $H$ pylori infection which is also common in members of the same family. ${ }^{27-29}$ In these subjects a genetic predisposition to duodenal ulcer disease has been suggested $^{3031}$ in which $H$ pylori may be the environmental factor which converts genetic predisposition into disease. We therefore conclude that in healthy blood transfusion donors no age related increase in serum pepsinogen $A$ and $C$ can be shown unless there is an infection with $H$ pylori. Serum pepsinogen A and C concentrations should be related therefore to the presence or absence of $H$ pylori infection.

1 Samloff IM. Cellular localization of group I pepsinogens in human gastric mucosa by immunofluorescence. Gastroenterology 1971; 61: 185-8.

2 Samloff IM, Liebman WM. Cellular localization of the group II pepsinogens in human stomach and duodenum by immunofluorescence. Gastroenterology 1973; 65: 36-42.

3 Samloff IM, Varis K, Ihamaki T, Siurala M, Rotter JI. Relationships among serum pepsinogen I, serum pepsinogen II, and gastric mucosal histology. Gastroenterology 1982; 83: 204-9.

4 Borch K, Axelsson CK, Halgreen H, Damkjaer Nielsen M, Ledin T, et al. The ratio of pepsinogen A to pepsinogen C: a sensitive test for atrophic gastritis. Scand $\mathcal{f}$ Gastroenterol 1989; 24: 870-6.

5 Ichinose M, Miki K, Furihata C, Kageyama T, Niwa H, Oka $\mathrm{H}$, et al. Radioimmunoassay of serum group I and group II pepsinogens in normal controls and patients with various disorders. Clin Chim Acta 1982; 126: 183-91.

6 Biemond I, Jansen JBMJ, Crobach LFSJ, Kreuning J, Lamers CBHW. Radioimmunoassay of human pepsinoge $\mathrm{A}$ and pepsinogen C. $\mathcal{F}$ Clin Chem Clin Biochem 1989; 27 19-25.

7 Pals G, Westerveld BD, Pronk JC, Frants RR, Défize J, Kostense PJ, et al. Enzyme linked immunosorbent assay of serum pepsinogen $A$ and $C$ in normal controls and patients with superficial or atrofic gastritis. [Thesis]. Amsterdam: Free University, 1986.

8 Jones DM, Eldridge J, Fox AJ, Sethi AJ, Whorwell PJ. Antibody to the gastric campylobacter-like organism ('Campylobacter pyloridis') - clinical correlations and distribution in the normal population. $\mathcal{f}$ Med Microbiol 1986; 22: 57-62

9 Perez-Perez GI, Dwarkin B, Choclos J, Blaser MJ. Campylobacter pylori-specific serum antibodies in human. Ann Intern Med 1988; 109: 11-7.
10 Marshall BJ, Warren JR. Unidentified curved bacilli in the stomach of patients with gastritis and peptic ulceration. Lancet 1984; i: 1311-3.

11 Blaser MJ. Helicobacter pylori and the pathogenesis of gastroduodenal inflammation. Infect Dis 1990; 161: 626-33.

12 Westerveld BB, Pals G, Lamers CBHW, Défize J, Pronk JC Frants RR, et al. Clinical significance of pepsinogen A isozymogens, serum pepsinogen $A$ and $C$ levels, and serum gastrin levels. Cancer 1987; 59: 952-8.

13 Oderda G, Vaira O, Holton J, Ainley C, Altare F, Ansaldi N. Amoxycillin plus Tinidazole for Campylobacter pylori gastritis in children: assessment by serum IgG antibody, gepsinogen I, and gastrin levels. Lancet 1989; i: $690-2$.

14 Peña AS, Endtz HPh, Offerhaus GJA, Hoogenboom Verdegaal A, van Duijn W, de Vargas N, et al. Value of serology (ELISA and immunoblotting) for the diagnosis of Campylobaçter pylori infection. Digestion 1989; 44: 131-41

15 Samloff IM, Liebman WM, Panitch NM. Serum group pepsinogens by radioimmunoassay in control subjects and patients with peptic ulcer. Gastroenterology 1975; 69: 83-90.

16 Samloff IM. Radioimmunoassay of group II pepsinogens in serum. Gastroenterology 1977; 71: A1125.

17 Waldum HL, Jarde R, Gunnes P. Renal excretion and the effect of posture on serum group I pepsinogens. Scand $\mathcal{F}$ Gastroenterol 1982; 17: 253-5.

18 Rauws EAJ, Langenberg W, Houthoff $\mathrm{HJ}$, Zanen $\mathrm{HC}$, Tytgat GNJ. Campylobacter pyloridis-associated chronic active antral gastritis: a prospective study of its prevalence and the antral gastritis: a prospective study of its prevalence and the
effects of antibacterial and antiulcer treatment. Gastroeffects of antibacterial and

19 Veenendaal RA, Biemond I, Peña AS, Kreuning J, Lamer CBHW. Serum pepsinogen $A$ and $C$ levels before and after treatment of Helicobacter pylori infection. Autumn meeting of the Dutch Society of Gastroenterology. Neth F Med 1991; 38: A13-4.

20 Hengels KJ, Jablonowski K, Schumacher B, Porschen R, Cooreman $M$, Barchard $\mathrm{F}$, et al. Serum pepsinogens: sensitive indicators of gastritis activity. In: Vilardell $F$, Hernandez, Guio C, eds. Proceedings of the third workshop of the European Helicobacter pylori study group. Rev Esp Enferm Dig 1990; 78 (suppl 1): P-168.

21 Dooley CP, Cohen H, Fitzgibbons PL, Bauer M, Appleman MD, Perez-Perez GI, et al. Prevalence of Helicobacter pylori infection and histologic gastritis in asymptomatic persons. $N$ Engl f Med 1989; 321: 1562-6.

22 Greenberg RE, Bank S. The prevalence of Helicobacter pylori in nonulcer dyspepsia. Importance of stratification according to age. Arch Intern Med 1990; 150: 2053-5.

23 Niedobitek F, Grosse G, Hammer M, Bonte G, Nehls R Volkheimer G. Gastritis and bacterial colonization of the gastric mucosa in adolescents. Am $\mathcal{F}$ Gastroenterol 1989; 84 $239-44$.

24 Villako K, Maards H, Tammur R, Kaevalik, Peetsalu M, Sipponen $\mathrm{P}$, et al. Helicobacter (Campylobacter) pylori infestations and the development and progression of chronic gastritis: results of long-term follow-up examinations of random samples. Endoscopy 1990; 22:114-7.

25 Sipponen P, Kekki M, Siurala M. The Sydney System epidemiology and natural history of chronic gastritis. epidemiology and natural history of

26 Samloff IM. Peptic ulcer: the many proteinases of aggression. Gastroenterology 1989; 96: 586-95.

27 Mitchell HM, Bohane TD, Berkowicz J, Hazell SL, Lee A Antibody to Campylobacter pylori in families of index children with gastrointestinal illness due to Campylobacte pylori. Lancet 1987; ii: $681-2$.

28 Jones DM, Eldridge J, Whorwell PJ. Antibodies to campylobacter pylori in household contacts of infected patients. BMF 1987; 294: 65

29 Oderda G, Vaira D, Holton J, Ainley C, Altare F, Boero M Smith A, Ansaldi N. Helicobacter pylori in children with peptic ulcer and their families. Dig Dis $S c i .1991 ; 36: 572-6$.

30 Rotter JI, Sones JQ, Samloff IM, Richardson CT, Gursky JM Walsh JH, et al. Duodenal ulcer disease associated with serum pepsinogen I. An inherited autosomal dominant serum pepsinogen I. An inherited autoso
disorder. NEngl f Med 1979; 300:63-6.

31 Rotter JI, Peterson G, Samloff IM, McConnell RB, Ellis A Spence A, et al. Genetic heterogeneity of hyperpepsinogenemic I and normopepsinogenemic I duodenal ulce disease. Ann Intern Med 1979; 91: 372-7. 